\title{
Abiodun Salawu* \\ Essentials of indigenous languages to journalism education in Nigeria
}

\begin{abstract}
This paper advocates for compulsory inclusion of indigenous languages in the mass communication/journalism curricula in Nigeria. Emphasising the point that every educational programme should be socially relevant and culturally sensitive, the paper argues that while it is not out of place for a journalist to be global in orientation and application, thereby equipping himself with proficiency in a very international language like English, it will, however, be out of place for him not to be able to communicate effectively with his very own people. This report concludes by calling for appreciation of the indigenous languages and support for the media's use of them, from both the people and the governments.
\end{abstract}

Key words: indigenous languages, mass communication/journalism curricula, Nigeria.

* Dr Abiodun Salawu is a Senior Lecturer and Head, Department of Communication and Media Studies at Ajayi Crowther University in Oyo, Nigeria. Mailing address: salawuabiodun@yahoo.com 


\section{INTRODUCTION}

Every educational programme should be socially relevant and culturally sensitive. In other words, application of learning outcomes should benefit the immediate community of the learner and should suit and impact on the learner's cultural background. Any educational programme that seeks to isolate the learner from his cultural background should be held suspect. After all, as Ehindero (1986:13) notes, the aims of education and curriculum are to serve the society in some important ways, which include:

(i) preserving, rediscovering and critically transmitting the cultural heritage; and

(ii) contributing to the improvement of the society by helping to refine and redefine national aims and techniques (indigenous and contemporary) through the use of the best and most relevant knowledge, currently available.

So, every curriculum should strive to be sensitive to and reflect this important value. Communication is not possible without language. Again, language occupies a central position in the aspects of culture. Thus, any curriculum for communication education, and precisely, in this case, journalism education, is expected to pay a high premium to the issue of language. For a journalism curriculum to be socially relevant and culturally sensitive, it must emphasise teaching in the indigenous language(s) of the society, which such learning outcomes will benefit. While the universality of education is recognized, the social and cultural specificity of the nature of training cannot be downplayed. While it is not out of place for a journalist to be global in orientation and application, thereby equipping himself with proficiency in a very international language like English, it will, however, be out of place for him if he is not able to, effectively, communicate with his own very people. Again, while we appreciate and grapple with the use of information technologies for the better communication within and around the world, our indigenous languages still remain relevant. The appreciation of technologies does not discard our languages. What we rather need to do is to harness the opportunities and potential of the hardware and let our languages as software use them as a vehicle for transmission.

Unfortunately in Nigeria and, presumably in most other African countries, journalism curricula have not prioritised indigenous languages. While English is studied by every student at Nigerian tertiary institutes, such as the Nigerian Polytechnics and the Universities, the teaching and learning of indigenous languages are underemphasised.

Aside from Journalism/Mass Communication Curriculum for Nigerian Universities, admission requirements for journalism education, both at Polytechnic and University levels, do not give any special recognition to indigenous languages. The above are the issues the present paper intends to highlight.

\section{LANGUAGE AND COMMUNICATION}

Berlo (1960:172) defines language thus: 
A system involving both elements and structures. As in any system, we can define elemental and structural units at many levels, depending on purpose. At any level, however, language includes a set of symbols (vocabulary) and the meaningful methods of combining those units (a syntax).A grammar [emphasis provided] is the description of the structural characteristics of language.

Here Berlo defines language in terms of elements and structures within the system. Other scholars have concentrated more or less on different aspects of the phenomenon. Block and Trapper (1942:5), for instance, focus on the social function of language. According to them, language is 'a system of arbitrary vocal symbols by means of which a social group co-operates'.

Hall (1968:158) defines language as 'the institution whereby humans communicate and interact with each other by means of habitually used oral-auditory arbitrary symbols'.

Noting that no particular definition of language can be exhaustive, Robin (1964:14) stresses the flexibility and adaptability of language thus: 'Languages are infinitely extendable and modifiable to the changing needs and conditions of speakers'. This, therefore, underscores the fact that language is adaptable to new situations, new ideas, new aspects of culture (Elugbe, 1991).

A number of theories have been propounded about the origin of language. From the assumptions of these theories, Berlo (1960:173) draws out some implications, which are:

1. Language consists of a set of significant symbols (vocabulary) plus meaningful methods for their combination (syntax).

2. The symbols of a language were chosen by chance. They are not fixed or Godgiven.

3. Man constructed his own language under the same principles of interpretation, response, and reward that govern all learning.

4 Man gradually created languages in order to express meanings to himself and others, to get other people to have the same meanings, and to make responses that increased his ability to affect.

From the above, we can deduce that language is innate and unique to man; captures man's world of reality; serves as the vehicle of man's interaction (communication) with others and that no language is superior to others.

Reinforcing language as a distinct characteristic of homo sapiens, Greenberg (1971: 156) puts it thus:

Language is unique to man. No other species possesses a truly symbolic means of communication and no human society, however simple its material culture, lacks the basic human heritage of a well developed language.

The central idea of the Sapir-Whorf hypothesis is that language functions, not simply as a device for reporting experience, but also, and more significantly, as a way of defining experience for its speakers. Sapir (1931:578), for example, says: 
Language is not merely a more or less systematic inventory of the various items of experience which seem relevant to the individual, as is so often naively assumed, but is also a self-contained creative symbolic organization, which not only refers to experience largely acquired without its help but actually defines experience for us by reason of its formal completeness and because of our unconscious projection of its implicit expectations into the field of experience. In this respect, language is very much like a mathematical system, which, also, records experience in the truest sense of the word only in the crudest beginnings, but as time goes on, becomes elaborated into a self-contained conceptual experience in accordance with certain accepted formal limitations... (Meanings are) not so much discovered in experience as imposed upon it, because of the tyrannical orientation in the world.

This thesis seems to have had its initial formulation in an article of Sapir first published in 1929:

Language is a guide to 'social reality'. Though language is not ordinarily thought of as of essential interest to the students of social science, it powerfully conditions all thinking about social problems and processes. Human beings do not live in the objective world alone, nor alone in the world of social activity as ordinarily understood, but are very much at the mercy of the particular language which has become the medium of expression for their society. It is quite an illusion to imagine that one adjusts to reality essentially without the use of language and that language is merely an incidental means of solving specific problems of communication or reflection. The fact of the matter is that the 'real world' ' is to a large extent unconsciously built upon on the language habits of the group. No two languages are sufficiently similar to be considered as representing the same social reality. The worlds in which different societies live are distinct worlds, not merely the same world with different labels attached (Mandelbaum, 1942:162 quoting Sapir, 1929).

It is evident from these statements that language plays a significant role in the totality of culture. Hoijer (1982:211) says language, far from being simply a technique of communication, is itself a way of directing the perception of its speaker and it provides for them habitual modes of analysing experience into significant categories.

Greenberg (1971: 156) moves this thesis further when he writes:

Language is the prerequisite for the accumulation and transmission of other cultural traits. Such fundamental aspects of culture as organized political life, legal systems, religion and science are inconceivable without that most basic human of tools, a linguistic system of communication. Language is not only a necessary condition for culture, it is itself part of culture. 
If we agree that language reflects the culture of a people, it is logical to say that people would express themselves and their cultures better in the language of their own culture. Communication is better enhanced in a medium that expresses the totality of the culture of a given people.

Chieka (1982:45) argues, further, the case for the use of language for the development of application of culture:

Each local language has always been down the millennia, at once an integral part, a repository and a vehicle of expression and transmission of its culture. Naturally, therefore, it has hitherto been part of the development and application of that culture. In reality can hardly be fully developed and applied outside language and conversely.

Expressing his concern for the dwindling fortunes of the nation's culture, Chieka (1982:45) exclaims, calling for urgent measures for improved 'communication and communion among the people' in 'our languages':

There is also the possibility of losing much of our culture if no deliberate and directed effort is made to develop and apply it to the daily lives of the rising generation of Nigerians as expressed in language. It has further become necessary to rationalize our language policies and reassure our people about the future of our languages while at the same time striving to increase and improve communication and communion among our people.

Local language as a medium of communication, Chieka (1982) stresses further, is important to the ordinary folk, especially men and women of the older generation, for most of whom it is still the only verbal medium of expression of self and culture.

Nigeria's immediate past president, (Chief) Olusegun Obasanjo, supported this assertion. In his remarks at the opening ceremony of a Colloquium on Black Civilization and Education in the late 1970s (when he was a military Head of State), he observed (Iwara, 1988):

It is now generally recognized that language is probably the single most characteristic element of any culture, and that it is an unmitigated tragedy for any human group to be unable to work in its own indigenous form.

Unfortunately, this is the situation with us in Nigeria where people take pride in their (sincere or feigned) inability to read and write in their own language. When we consider the following statement by Elugbe (1991: 44), we find that ours is an irony:

People are just as attached to their languages as they are to other aspects of their culture such as religion. But while people may easily give up a 
religion, a way of dressing, a political system, and so on, it is not easy to make them give up their language.

Yet, no language is superior to any other. Hymes (1961) posits that 'all known languages roughly manifest the same kind of symbolic behaviour system, in spite of their great variety'.

Ferguson (1968:28) puts it more succinctly:

There is no simple scale of superiority in structure and no simple evolutionary line along which known linguistic structures could be placed. In this fundamental sense, there is as yet no convincing evidence that the total structure of one language is better than that of another in that it is easier to acquire (as a first language), less ambiguous, more efficient for cognitive processes, or more economical of effort in oral use, let alone more logical, 'expressive’ or the like.

Ngugi (1993:36) offers an explanation of the positions of West European languages and African languages:

Today, the West European languages and African languages are where they are in relation to one another, not because they are inherently progressive or backward but because of the history of oppression on the one hand, and the resistance to that oppression on the other.

Recognizing, though, that the West European languages are the language of power, Ngugi (1993:37) nevertheless contends:

But they are still spoken only by a minority within each of the nationalities that make up those countries. The majority of the working people in Africa retain our African languages. Therefore, the majority of the people are excluded from centre stage since they do not have mastery of the language of power. They are also excluded from any meaningful participation in modern discoveries. English, French and Portuguese are the languages in which the African people have been educated, for this reason the results of our research into science, technology and of our achievements in the creative arts are stored in those languages. Thus a large portion of this vast knowledge is locked up in the linguistic prison of English, French and Portuguese. Even, the libraries are really English (or indeed French or Portuguese) language fortresses inaccessible to the majority. So, the cultivation of these languages makes for more effective communication only between the elite and the international English-speaking bourgeoisie.

Thus, he sees writing in these European languages as parochial (Eyoh, 1986:111). In consonance with what has been earlier discussed, Ngugi says language has a dual character - a means of communication and a carrier of culture. 
He (1993:30) expresses the idea further this way:

Every language has two aspects. One aspect is its role as an agent that enables us to communicate with one another in our struggle to find the means for survival. The other is its role as a carrier of the history and the culture built into the process of that communication over time.

Taking his customary Marxian perspective, Ngugi (1986) says language as communication has three aspects or elements. The first, according to him, is 'what Karl Marx once called the language of real life, the element basic to the whole notion of language, its origins and development: that is, the relations people enter into with one another in the labour process, the links they necessarily establish among themselves in the act of a people, a community of human beings, producing wealth or means of life like food, clothing, houses'.

The second aspect is speech and it imitates the language of real life, which is communication in production. While the third aspect is the written signs. The written word, he notes, imitates the spoken word.

Then, he suggests (Ngugi, 1986:16):

Since the new language as a means of communication was a product of and reflecting the 'real language of life' elsewhere, it could never as spoken or written properly reflect or imitate the real life of that community. This may, in part, explain why technology always appears to us as slightly external, their product and not ours.

\section{CURRICULUM AND JOURNALISM EDUCATION IN NIGERIA}

The etymology of curriculum is traced to a Latin word 'currus', which simply means a running course or racetrack for chariots. Curriculum, as we know it today, means structured plan of action that guides the process of education. Curriculum entails all the learning opportunities that are planned and offered to the child during the process of schooling.

Tyler (1949) defined curriculum as 'a set of planned learning experiences offered in the school'. Tyler counsels that if curriculum is to serve its real purpose, it must assist the pupil to see the value of the past in relation to the present and the future. It must equip the child with the necessary skills for modern living and it must help to keep the child a fully integrated member of his community. The question we may want to ask here is this: to what extent is the current journalism curriculum in Nigeria assisting the student journalist to see the value of the past in relation to the present and the future? The current Journalism/Mass Communication Curriculum for Nigerian Universities as drawn up by the National Universities Commission (NUC) provides for the teaching of a course in African Indigenous Communication Systems. The National Board for Technical Education (NBTE) Journalism/Mass Communication Curriculum for Nigerian Polytechnics does not make any provision for this. Even in certain Nigerian universities where Mass Communication-related disciplines are offered, no 
regard is given to the African Indigenous Communication System in the undergraduate programme. An example is the Communication and Language Arts (undergraduate) programme of the University of Ibadan. The course is, however, offered in the Masters' programme of the Department (Dept. of CLA, 1988).

The aim of the African Indigenous Communication Systems course is to teach the students about how Africans in the past, before the advent of printing and broadcasting technologies on the continent, were communicating with one another in diverse settings. But beyond this, Tyler (1949) advocates that a curriculum must equip the learner with the necessary skills for modern living while still keeping him a fully integrated member of his community. Modern communication modes are characterized by printing, broadcasting and the Internet. A modern Nigerian journalist must avail himself of these technologies, but remain a fully integrated member of his community, the journalist must be able to communicate in the language of his community language being the totality of expression of his people's culture.

To corroborate this assertion, Walton (1971:2) defines curriculum as 'those aspects of the culture that are selected to be transmitted ... to succeeding generations...'. In actual fact, the core of education is the cultural heritage which each generation deliberately provides to its successors and which is deemed to be instrumental to the survival of succeeding generations (Ehindero, 1986:17). Having stated the foregoing, Ehindero (1986:17) defines education thus:

Any worthwhile and valuable cultural artifact purposefully induced, either by oneself or by others, and which are selectively and consciously transmitted, modified and transformed from one generation to the next in or outside a formalized social institution.

At the risk of over-emphasis, language is very central to culture. If a culture must survive, the language must be constant. If a language must have life so as to be constant, the media must be seen to be using it. In other words, the survival of our language is, in some way, dependent on the media (Salawu, 2001; 2004). And if the media, print especially, must use it, the practitioners must be trained to use it. Therefore, we must tailor our curriculum towards achieving this objective. After all, Ehindero describes curriculum, structurally, as a man-made open system with an array of interacting components (pillars and elements) organized in a logical pattern so as to constrain action towards the fulfillment of educational aims and purposes. The pillars of curriculum he identifies are philosophy, society/culture, knowledge and psychology (Ehindero, 1986:35).

This present paper is not oblivious to the fact of history, which made the situation with our language and education what it is. Colonialism foisted the languages of colonial masters on Africans and elevated the languages over the indigenous languages of the Africans. Colonialism, of course, affects the African psyche and various aspects of the African life, including curriculum design. Blackemore and Cooksey (1981) see it as a matter of ideology. Hence, they note:

The ideological content of the school curriculum was very apparent during the colonial era. In those times, students learned of European 
history, culture and science; African achievements and culture were played down. Certain areas of knowledge are rarely included in the school curricula even to day.

Ehindero identifies certain approaches to philosophy of curriculum. They are perennialism, essentialism, pragmatism and existentialism. Almost all of these approaches have something to say for the use of indigenous languages in journalism education in Nigeria. For instance, the perennialist approach gives regard to fixed patterns of Nigeria's value and culture system amid societal science and technological changes. Ehindero (1986: 89) comments:

An education that can cope with the techno-scientific and social needs of Nigerians today and in the future demands that the curriculum be intellectual, socially relevant and culturally sensitive.

The pragmatists insist that because of socio-cultural variations and genetic differences in man, the method, quality and products of education are bound to differ. With the experience and society-oriented interactional nature of pragmatists' education, a curriculum that is process-oriented and community-relevant is recommended for schools (Ehindero, 1986). So, for journalism education to be community-relevant, it must, among other things, be sensitive to the language of the community. A relevant comment is also made in this regard (Ehindero, 1986:119):

Curriculum scholars have a recurring cliché that insists that institutions of learning and their curriculum are inseparable from the social context in which they function. In this context, the curriculum can be regarded as a product of cultural selection and social engineering in which the school, an expression and a reflection of the collective and accumulated culture of the society, processes both people and knowledge into each group's ways of behaviour.

\section{JOURNALISM EDUCATION IN NIGERIA}

Journalism training in Nigeria started in an informal way. It started in 1954 with a twoweek vocation course for working journalists at the University of Ibadan. Two years later a two-year in-service journalism training was organized for Nigerian radio broadcasters by the news department of the Nigerian Broadcasting Corporation, now Federal Radio Corporation of Nigeria (Akinfeleye, 1996; 2003). In 1959, the then United States Information Services (USIS), now the Public Affairs Department of the United States Embassy, sponsored a journalism traveling workshop. In 1960, the International Federation of Journalists conducted a Nigerian journalism course.

Formal training in journalism started in Nigeria in 1962 with the establishment of Jackson College of Journalism at the University of Nigeria, Nsukka. The college was later turned into the Department of Mass Communication of the institution. Since then, other departments/schools of journalism or mass communication in various Nigerian 
Universities have sprung up, notably among which is that of the University of Lagos, Akoka.

Akinfeleye (2003) reports that there are 48 journalism institutions in Nigeria, 23 of which are an integral part of universities (JAMB, 2002) while 13 are an integral part of polytechnics (JAMB, 2003). Notable among journalism institutions that are neither parts of universities nor polytechnics are the Nigerian Institute of Journalism (NIJ) founded in 1971 and the Times Journalism Institute.

Writing about the aims and objectives of journalism education in Nigeria, Akinfeleye (2003) notes:

The aims and objectives of the journalism programmes in

Nigeria are to train journalists, educate them and make them responsible and useful citizens of Nigeria as they use their journalistic expertise to build a new Nigeria.

Referring to the provisions of NBTE and NUC, Akinfeleye (2003) gives the more specific objectives of journalism education as:

(a) producing graduates who are to meet the middle-and-higher level manpower communication requirements of Nigeria;

(b) producing qualified communication/journalism teachers for the universities, polytechnics and other similar institutions;

(c) producing technically qualified graduates who can be self-employed upon graduation; and

(d) producing socially responsible journalists and communicators.

\section{ADMISSION REQUIREMENTS AND JOURNALISM CURRICULUM IN NIGERIA: IMPLICATIONS FOR INDIGENOUS LANGUAGE}

Despite the fact that mass communication is located in different faculties across Nigerian universities, the admission requirements are similar. The requirement for a credit in English language in the Ordinary Level results is constant for all the universities. For instance, in the universities, which have their mass communication department under Faculty of Administration, the Ordinary Level requirement for University Matriculation Examination (UME) candidates is: 'Five ' $\mathrm{O}$ ' level credits to include English Language, Literature-in-English, and Government plus at least a pass in Mathematics' (JAMB, 2002:56). For Mass Communication under Faculties of Arts/ Humanities, the requirement is: 'Five ' $\mathrm{O}$ ' level credits to include English Language' (JAMB, 2002:99). For faculties of social sciences, the Ordinary Level requirement for admission into Mass Communication is: 'Five ' $O$ ' level credits in English and four other subjects in Arts or Social Sciences’ (JAMB, 2002:235).

An inference to draw from the constancy of English Language in all these requirements is that language is inevitable to the discipline of journalism/mass communication. But, if it is language, why must it be English alone? We appreciate the fact of our colonial history. But what happens to the language of the people, which the universities and journalists trained there must, immediately, serve? 
In Nigeria, mass communication also comes in another guise. At some other universities, disciplines like Communication Arts or Communication and Language Arts also exist. Here also, the requirement for English Language remains constant: 'Five ' 0 ' level credits or equivalents including English Language, Literature-in-English, Arts/Music depending on the combination' (JAMB, 2002:104).

One noticeable requirement for the UME subjects (i.e. subjects a Mass Communication candidate is required to sit for) for almost all the universities is that of Literature-inEnglish. (The Use of English is compulsory for all candidates irrespective of disciplines). Why not literature in any indigenous language? The only exception to all the fore-going observations is found in situations where an indigenous language is combined with Communication Arts as a Course of Study. Such examples are EfikIbibio with Communication Arts offered at the University of Uyo; and Yoruba and Communication Arts, offered at the Lagos State University (LASU), Ojoo. The LASU programme is clear in its offer and requirements. For instance, for Direct Entry candidates into the programme, the requirement is a 'Diploma in Yoruba/Yoruba and Communication Arts, NCEYoruba, Diploma in Journalism, Mass

Communication,Yoruba Linguistics, Certificate and other relevant subjects' (JAMB, 2002:105).

The Ordinary Level requirement for UME candidates is: 'Five ' 0 ' level credits in English language, Yoruba, History, Islamic Studies, CRS, French, Hausa, Igbo, Government and Economics’ (JAMB, 2002:105).

The UME subjects for the programmes are Yoruba, Literature-in-English and any Arts or social science subject.

What is obvious from the fore-going is that it is only in instances like that of LASU where communication is combined with an indigenous language as a Course of Study that the indigenous language is given recognition at all. In this case of LASU, not only Yoruba, which is the University's immediate environment's language, is recognized, other Nigerian major languages - Hausa and Igbo - are also recognized. Yet, the LASU requirements remain sensitive to the nation's reality by according English its due recognition in the ' 0 ' level requirements and the UME subjects.

Concerning admission requirements, the situation at the polytechnics and other journalism institutions is not different, compared to those of universities. In fact, Kaduna Polytechnic is even unequivocal that it 'does not accept any Nigerian language among the course requirement'. In the polytechnic category, Lagos State Polytechnic is the only one with a consideration for indigenous language. It accepts an $\mathrm{O} / \mathrm{L}$ credit in Yoruba as course requirement (JAMB, 2003).

Similarly, the Journalism/Mass Communication Course Curriculum does not have any (special) room for indigenous language. However, without any bias, there is equally no special room for English Language in the Universality Mass Communication Curriculum. The only saving grace for English in this instance is the General University Requirement for the compulsory taking of Use of English, among other General Studies (Courses), by all university students, regardless of disciplines.

The situation is, however, different in the polytechnics and other journalism institutions. For instance at the polytechnic level, the NBTE requires that special English courses for Mass Communication be taught at the National Diploma (ND) level (NBTE, 1990). This covers all the four semesters of the programme. It is also important 
to note that in the first year of the ND programme, it is compulsory for every student to take either one indigenous language or French (NBTE, 1990). Here, though indigenous language is recognized, it is still optional. This requirement does not exist for the Higher National Diploma programme.

All the same, there are obvious lapses in the English language proficiency of journalism/mass communication students. This problem is even carried over to their professional practice after graduation. This paper prescribes that English syntax and phonetics should be well taught to journalism/mass communication students. This, however, should not be at the expense of indigenous languages.

\section{CONCLUSION}

For journalism and journalism education in Africa to be authentic, the indigenous language must be seen as inevitable in the venture. Sheer disregard for our language(s) in the enterprises indicates we are not ready to be natural, original and sensitive to our reality. There is no way we can wish away our history, our culture, our being, our essence and our reality. This is just exactly as it may be inexpedient for us to wish away the European languages in our national and international lives. What is important for us now is not to allow the legacy of colonialism to continue to threaten the integrity of our culture, our language. We owe this to posterity.

In Yorubaland (Nigeria) today, there are a myriad of Yoruba newspapers serving the people. This attests to the viability of journalism in indigenous languages. Some of the publications have been noted to be doing well in the market (See The Fourth Estate, 2004:7; Salawu, 2006). But, given the available population, one expects this segment of our press to have gone higher than the level it is, presently, in terms of readership and patronage as well as managerial and editorial performance of the newspapers. Governments, academic/professional regulatory bodies and training institutions have a role to play in the embrace of our languages, and the sustenance and improvement in the practice of journalism in the particular segment of our press. This paper, yet, maintains that journalism training must cater to this segment of the industry in the full realization that journalism does not necessarily collocate with European languages. Our journalism curriculum, in this regard, must be society-oriented.

This paper recalls an observation by Ehindero (1986:276) when he notes that research in curriculum studies is not restricted to empirical or experimental investigations, but also covers those scholarly activities, whether historical, sociological or philosophical, which while they may discover new facts or rediscover old ones are often mainly concerned with the reinterpretation of facts already well known. He later submits:

In the light of the above, research in curriculum studies is simply a form of critical reflection, upon historical, contemporary, social and cultural experiences, including the systematic search for an interpretative framework of what is novel in experience. 


\section{REFERENCES}

Akinfeleye, R.A. 1996. Journalism education and training in Nigeria: infrastructure policies and development. In Dare, O. and Uyo, A. (eds). Journalism in Nigeria: issues and perspectives. Lagos: NUJ Lagos Council.

Akinfeleye, R.A. 2003. Fourth estate of the realm or fourth estate of the wreck: imperative of the social responsibility of the press. Inaugural lecture, University of Lagos: Nigeria.

Berlo, D.K. 1960. The Process of communication. San Francisco: Rinehart Press.

Blackmore, K. \& Cooksey, E.A..1981. Sociology of education for Africa.London: George Allen \& Union.

Block, B. \& Trapper, G.L..1942. Outline of linguistic analysis. Baltimore: Linguistic Society of America/Waverly Press.

Chieka, I. 1982. The place of local languages in Nigeria oday’. In Ikara, B. (ed.). Nigerian languages and cultural development. Lagos: The National Language Centre, Federal Ministry of Education.

Department of Communication and Language Arts, University of Ibadan, Handbook Ibadan: Transcode Limited. 1998.

Ehindero, S. 1986. Curriculum foundations and development for Nigerian students. Lagos: Concept Publications Ltd.

Elugbe, B. 1991. Language and culture. In Lloyd Thompson (ed.) Culture and civilisation. Ibadan: Africa - Link Books.

Eyoh, H.N. 1986. 'Theatre of relevance: an interview with Ngugi Wa Thiong’ o’. African Theatre Review. 1(2):110-114. Ibadan: Heinemann Educational Books.

Fergusson, C.A. 1968. 'Language development'. In Fishman, J.A. (ed.) Language problems of developing nations. New York: John Wiley.

Greenberg, J.H. 1971. Language, culture and communication. Selected by A.S. Dil. Stanford:.Stanford University Press.

Hall, R. A. 1968. An essay on language. New York: Chilton Books.

Hoijer, H. 1982. 'The Sapir-Whorf hypothesis'. In. Samovar, L.A. \&. Porter, R.E. (eds.) Intercultural communication: a reader. Belmont Calif: Wadsworth Publishing Company.

Hymes, D.H. 1961. Functions of speech: an evolutionary approach’. In Gruter, F. (ed.). Anthropology and education. Philadelphia: University of Pennsylvania Press.

Iwara, A.U. 1982. The development and modernisation of indigenous languages in Nigeria. Nigeria Magazine, 56(1\&2).

Joint Admissions and Matriculation Board. 2002. UME de brochure: guidelines for admissions to first degree courses in Nigerian universities 2003/2004 session. Lagos: JAMB.

Joint Admissions and Matriculation Board. 2003. M.P.C.E. Brochure: guidelines for admissions to programmes in monotechnics, polytechnics and courses in colleges of education, 2003/2004. Abuja: JAMB.

Mandelbaum, D.G. 1949. (ed.). Selected writings of Edward Sapir. Berkeley and Los Angeles: University of California Press.

National Board for Technical Education. 1990. National Diploma (ND) and Higher 
National Diploma (HND) in Mass Communication: Curriculum and Course Specifications. Kaduna: NBTE.

Ngugi, W.T. 1993. Moving the centre: the struggle for cultural freedoms. London: James Currey.

Ngugi, W.T. 1986. Decolonising the mind: the politics of language in African literature. London: James Currey.

Robins, R.H. 1964. General linguistics: an introduction. London:Longman.

Salawu, A. S. 2006. 'Paradox of a milieu: Communicating in African indigenous languages in the age of globalisation'. In A. S. Salawu (ed.) Indigenous Language Media in Africa. Lagos: CBAAC.Pp. 1 - 20.

Salawu, A.S. 2004. 'The Yoruba and their language newspapers: origin, nature, problems and prospects'. Studies of Tribes and Tribal. 2(2): 97 - 104.

Salawu, A.S. 2001. An evaluation of development communication content of Yoruba newspapers. Ph. D thesis, University of Ibadan, Nigeria.

Sapir, E. 1931. Conceptual categories in primitive languages. Science, 74:578.

The Fourth Estate, No. 9. Lagos: IJC/JODER, Nov./Dec., 2004.

Tyler, R.W. 1949. Basic principles of curriculum and instruction. Chicago: University of Chicago Press.

Walton, D. 1971. Introduction to education. A substantive discipline. Massachusetts Xerox College Publishing. 